\section{Vietnam Journal of Agricultural Sciences}

\title{
Effects of Organic Fertilizer and HB101 Plant Vitalizer on the Growth and Yield of Rice (Oryza sativa L.)
}

\author{
Nguyen Thi Loan ${ }^{1} \&$ Nguyen Ngoc Hung ${ }^{2}$ \\ ${ }^{1}$ Faculty of Agronomy, Vietnam National University of Agriculture, Hanoi 131000, \\ Vietnam \\ ${ }^{2}$ Hybrid Rice Research and Development Center, Field Crop Research Institute, Hanoi \\ 134000, Vietnam
}

\begin{abstract}
To study the effects of organic fertilizer and HB101 organic plant vitalizer on the growth and yield components of the BH9 rice variety, a field experiment with $4 \times 3$ factorial design was conducted at Hong Thai commune, Kien Xuong district, Thai Binh province in 2017 summer season using a randomized complete block design with 3 replications. Organic fertilizer derived from chicken manure and peat was applied at 3 levels $\left(0\right.$ ton $\mathrm{ha}^{-1}, 4$ tons ha $\mathrm{ha}^{-1}$, and 6 tons $\left.\mathrm{ha}^{-1}\right)$ while the HB101 plant vitalizer was sprayed in 4 levels $(0 \%$, $0.015 \%, 0.025 \%$, and $0.035 \%$; the amount of water to dilute HB101 was 1000 litre $\left.\mathrm{ha}^{-1}\right)$. The application of the organic fertilizer alone and the combination of organic fertilizer and HB101 positively increased the total tiller number, effective tiller number, leaf area index (LAI), SPAD value, dry matter accumulation, yield components, and grain yield of rice. There were also differences in the SPAD values (at flowering stage), dry matter weight (at active tillering stage), and 1000 grain weight under the influence of the HB101 solution. The combination of 6 tons $\mathrm{ha}^{-1}$ organic fertilizer and HB101 significantly increased the grain yield as compared to the other treatments, and the highest grain yield (3.03 tons ha-1) was obtained when organic fertilizer (6 tons $\left.\mathrm{ha}^{-1}\right)$ was applied in combination with HB101 plant vitalizer $(0.025 \%)$.
\end{abstract}

\section{Keywords}

Rice, grain yield, organic fertilizer, plant vitalizer

Received: July 13, 2018

Accepted: June 19, 2019

Correspondence to

ntloan@vnua.edu.vn

ORCID

Loan Nguyen

https://orcid.org/0000-0002-71948996

\section{Introduction}

Over the past few decades, the use of chemical fertilizers has widely increased throughout the world. However, the application of synthetic fertilizers is costly and can cause environmental problems. Excessive and continuous applications of fertilizers are associated with the depletion of soil organic matter (Ghoneim et al., 2007), 
high levels of residual nitrate and other toxins in the soil, which potentially lead to water and atmospheric pollution, soil acidity, and pest problems (Siavoshi et al., 2011). They may also adversely affect crop productivity and quality, which are attributed partly to the decreasing $\mathrm{N}$ supplying capacity of the soil. As such, it is important to sustain and improve the inherent $\mathrm{N}$-supplying capacity of the soil by increasing the potential of the nutrient recycling process in the soil (Javier et al., 2002). Nowadays, interest in organic agriculture is growing in order to maintain and improve soil quality, in addition to increasing crop yield and quality. Therefore, the effective use of organic materials from farm wastes in rice farming is also likely to be promoted.

The application of organic materials plays a vital role in agriculture because these materials supply various kinds of plant nutrients, including micronutrients, improve soil properties by stabilizing the $\mathrm{pH}$ and $\mathrm{CEC}$ of soil, maintain soil organic matter, increase the nutrient holding capacity and buffering capacity, control the soil moisture, and enhance the microbial activity and nutrient cycle in the soil (Ghoneim et al., 2007; Myint et al., 2010). These lead to soil stabilization, which is necessary for sustainable agriculture systems.

Many previous studies have reported the effects of organic materials on the growth and yield of rice. Myint et al. (2010, 2011) showed that tiller number, plant height, SPAD value, dry matter weight, and grain yield of rice drastically increased in all the organic manure treatments compared to the control with no fertilizer application. Ohyama et al. (1998) and Javier et al. (2002) recorded significant increases of rice grain yield under the consecutive application of organic materials over three years. Ghoneim (2007) indicated that the application of different kinds of organic materials including poultry manure and sewage sludge increased grain yield more than the treatment of inorganic fertilizer. Thereby, organic fertilizer has been shown to be as good as chemical fertilizer in improving the growth and yield of rice.
Organic methods in agriculture production have become increasingly popular as a result of consumer demand. Organic inputs can release a continuous and steady nitrogen source as needed by plants (Moe et al., 2017). However, if too much nitrogen is applied, whether in the form of organic matter or inorganic fertilizer, some of the excess nitrogen is converted to nitrate. If nitrate is not absorbed by plant roots, it is carried away by runoff or leaches into the soil along with water. Liu et al. (2014) reported that there are close relationships between the excessive amounts of nitrogen and both crop yield decreases and environmental problems such as soil and water pollution, eutrophication, the greenhouse effect, and acid rain. As a result, there is increasing interest in identifying the optimum doses of organic materials for their effectiveness in submerged crops such as rice.

HB101 is a natural growth promoter for plants, flowers, and crop production that is specially processed by blending organic extracts from renewable resources. This all-natural solution works to improve growth processes and support plant immune function, while helping to reduce the demand for costly chemicals (Mohammatdi et al., 2012). Thus, our goals were to study the influence of the integrated applications of different doses of organic fertilizer and organic solution HB101 on rice growth and yield.

\section{Materials and Methods}

A field experiment with $4 \times 3$ factorial design was conducted in the summer season of 2017 at Hong Thai, Kien Xuong, Thai Binh, Vietnam with the Bac Huong 9 (BH9) rice variety - a quality variety with a high yield potential. In July 2017, 3 x 5-m plots were made by inserting plastic frames into the subsoil layer in a large paddy field. The experiment was laid out in a randomized complete block design with three replications.

The first factor was the organic fertilizer provided by the Center for Organic Agriculture Promotion and Studies (COAPs) (Vietnam National University of Agriculture). It was produced from chicken manure and peat, and 
contained $1.1 \% \mathrm{~N}, 0.5 \% \mathrm{P}_{2} \mathrm{O}_{5}$, and $0.6 \% \mathrm{~K}_{2} \mathrm{O}$. The organic fertilizer was fully applied 3 days before transplanting at three levels: P0 (0 ton ha-1), P1 (4 tons ha' ${ }^{-1}$ ), and P2 (6 tons ha-1).

The second factor was HB101, a Japanese natural plant vitalizer made from essences of cedars, Japanese cypress, pines, and plantains. A mineral analysis from this product revealed the following information: $\mathrm{pH}$ (concentrate) $=$ $4.0 ; \mathrm{pH}(1000 \mathrm{X}$ dilution $)=6.5$; sodium 155.3 $\mathrm{mg} /$ gallon; calcium $125 \mathrm{mg} / \mathrm{gallon}$; iron 6.8 $\mathrm{mg} /$ gallon; magnesium $12.5 \mathrm{mg} /$ gallon; and silicon $28 \mathrm{mg} /$ gallon. HB101 in solution is reported to help strengthen the leaves' cells and stems' cell membranes, increase the plant's photosynthetic efficiency, enhance the activity of soil micro-organisms, and maintain the balance of plant nutrients according to the manufacturer. These result in stronger root, stem, and leaf systems, and stronger, healthier plants. In this study, the HB101 solution was applied with four spray concentrations by volume: N0 (0\%), N1 (0.015\%), N2 (0.025\%), and $\mathrm{N} 3(0.035 \%)$. The amount of water used to dilute the HB101 solution for 1ha was 1000 litres. The diluted HB101 solution was applied two times using a hand spray bottle: 10 days after transplanting and at the flowering stage.

Rice was transplanted with three seedlings per hill at a density of 25 hills $\mathrm{m}^{-2}$ with $25 \mathrm{~cm} \mathrm{x}$ $25 \mathrm{~cm}$ spacing. Irrigation was conducted as a common management practice together with the surrounding area. Hand weeding was conducted as necessary. Disease control measures, which are recommended for rice, were followed to prevent any disease.

Soil samples $(0-15 \mathrm{~cm})$ were collected before the fertilizer applications to determine the soil $\mathrm{pH}$, percentage of organic matter $(\mathrm{OM})$, percentage of total nitrogen, exchangeable nitrogen, total phosphorus, and total potassium. The soil characteristics were analysed in the Center for International Plant Research Vietnam - Japan (Vietnam National University of Agriculture).

The growth indicators, including plant height, number of leaves per main tiller, and number of tillers per hill, were measured weekly on five plant samples from each experimental plot. Another five plant samples were harvested at the effective tillering stage, flowering stage, and maturity stage for measurements of SPAD values and leaf area index (LAI). SPAD values were measured using a chlorophyll meter (Konica Minolta Chlorophyll meter SPAD 502 (Japan)), then the sample leaves and the remaining leaves were dried separately in an oven at $80^{\circ} \mathrm{C}$ for $48 \mathrm{~h}$ for the determination of the dry matter weight.

At harvest time, the number of panicles per $\mathrm{m}^{2}$ of soil, number of grains per panicle, thousand-grain weight, filled grain rate, and grain yield were measured; grain yield was recorded from the sampling area $\left(5 \mathrm{~m}^{2}\right)$ of each experimental plot.

Analysis of variance (ANOVA) was performed to determine the effects of fertilizer levels, HB101 spray levels and their interaction using the CROPSTAT software. Least significant difference (LSD) at the 5\% level of probability was used to evaluate the differences among treatment means.

\section{Results and Discussion}

\section{The results of the soil analysis before fertilization}

The results of the soil analysis showed that the soil sample was neutral in terms of $\mathrm{pH}(\mathrm{pH}$ $=6.55)$, and considered high in organic matter $(2.17 \%)$, medium in total nitrogen $(0.165 \% \mathrm{~N})$, medium in available nitrogen $(12 \mathrm{mg} / 100 \mathrm{gr}$ soil), low in total phosphorus $\left(0.035 \% \mathrm{P}_{2} \mathrm{O}_{5}\right)$, and low in total potassium $\left(0.26 \% \mathrm{~K}_{2} \mathrm{O}\right)$.

\section{The effects of the organic fertilizer doses and HB101 spray levels on the plant growth characteristics}

High doses of organic fertilizer led to increased plant growth parameters. The highest values of all the plant growth parameters were recorded in the P2 treatment. There were no significant differences in the mean plant height and number of leaves under organic fertilizer application; however, the organic fertilizer doses dramatically affected the total number of tillers and the number of effective tillers of rice. 
In terms of the HB101 solution, there were no significant differences among treatments in all the measured plant growth parameters. Higher application levels of HB101 tended to increase the number of effective tillers (Table 1).

The interacting effects of the organic fertilizer doses and HB101 spray levels on the plant growth indicators are shown in Table 2. There were no significant differences in the plant height and number of leaves among the treatments, but all the treatments recorded significant differences among the number of total tillers and effective tillers. High spray levels of the HB101 solution significantly increased the number of tillers and effective tillers per hill under the $\mathrm{P} 1$ and $\mathrm{P} 2$ treatments in comparison with the $\mathrm{P} 0$ treatment. The highest tiller number and effective tiller number were recorded under the P2N3 treatment with 8.87 tillers and 7.93 tillers, respectively.

Increases in plant growth under different rates of organic inputs have been recorded in previous studies. In the study of Siddaram et al. (2010), the different growth parameters such as plant height and the number of tillers were significantly influenced by various levels of nitrogen through organic sources. Myint et al. (2010) and Siavoshi et al. (2011) observed significant increases in plant height and total tiller numbers under high applied doses of poultry manure in their experiments. Gautam (2013) and Gafar et al. (2014) indicated that increased applications of organic fertilizer resulted in significant increases in the number of effective tillers.

Higher values of the plant growth indicators, including the number of tillers and number of leaves, might be due to the higher availability of nitrogen from the organic fertilizer and a possible increase in the nutrient absorption capacity of the plants as a result of better root development and increased translocation of carbohydrates from sources to growing points (Siavoshi et al., 2011). In the study of Siddaram et al. (2010), the significant increase in plant height might have been due to the greater availability of nutrients from organic sources. Similar results were observed in the studies of Ghoneim (2007) and Singh et al. (2017), who indicated that organic sources positively affected plant growth due to offering more balanced nutrition to the plants, especially micronutrients, and enhancing the availability of soil microorganisms that are able to convert the unavailable forms of nutrient elements to available forms. In our present study, the differences in the mean plant heights and number of leaves were not recorded, however, the number of total tillers and effective tillers were significantly different. These results were

Table 1. Effects of the organic fertilizer doses and HB101 spray levels on plant growth characteristics of rice variety BH9 in the summer season

\begin{tabular}{|c|c|c|c|c|}
\hline Treatment & $\begin{array}{l}\text { Plant height } \\
\quad(\mathrm{cm})\end{array}$ & $\begin{array}{l}\text { Tiller number } \\
\text { (tillers per hill) }\end{array}$ & $\begin{array}{l}\text { Effective tiller number } \\
\text { (tillers per hill) }\end{array}$ & $\begin{array}{l}\text { Leaf number } \\
\text { (leaves per tiller) }\end{array}$ \\
\hline \multicolumn{5}{|c|}{ Organic fertilizer doses } \\
\hline 0 ton ha ${ }^{-1}(\mathrm{P} 0)$ & $107.4^{\mathrm{a}}$ & $8.00^{\mathrm{b}}$ & $6.90^{\mathrm{b}}$ & $10.8^{a}$ \\
\hline 4 tons ha ${ }^{-1}(\mathrm{P} 1)$ & $107.5^{\mathrm{a}}$ & $8.28^{\mathrm{ab}}$ & $7.38^{\mathrm{a}}$ & $10.8^{\mathrm{a}}$ \\
\hline 6 tons ha $^{-1}(\mathrm{P} 2)$ & $110.1^{\mathrm{a}}$ & $8.55^{a}$ & $7.47^{a}$ & $11.0^{\mathrm{a}}$ \\
\hline $\mathrm{LSD}_{0.05 \mathrm{P}}$ & 5.41 & 0.32 & 0.47 & 0.60 \\
\hline \multicolumn{5}{|c|}{ HB101 spray levels } \\
\hline $0 \%(\mathrm{~N} 0)$ & $108.5^{\mathrm{a}}$ & $8.24^{\mathrm{a}}$ & $7.02^{\mathrm{a}}$ & $10.8^{a}$ \\
\hline $0.015 \%(\mathrm{~N} 1)$ & $109.4^{\mathrm{a}}$ & $8.31^{a}$ & $7.33^{\mathrm{a}}$ & $10.9^{a}$ \\
\hline $0.025 \%(\mathrm{~N} 2)$ & $107.6^{\mathrm{a}}$ & $8.20^{\mathrm{a}}$ & $7.20^{\mathrm{a}}$ & $10.8^{a}$ \\
\hline $0.035 \%(\mathrm{~N} 3)$ & $107.8^{a}$ & $8.36^{a}$ & $7.44^{\mathrm{a}}$ & $10.8^{a}$ \\
\hline $\mathrm{LSD}_{0.05 \mathrm{~N}}$ & 6.25 & 0.36 & 0.55 & 0.69 \\
\hline
\end{tabular}

Note: Values followed by different letters within a column indicate significant differences at a $5 \%$ probability level. 
Table 2. Interacting effects of the organic fertilizer doses and HB101 spray levels on the plant growth characteristics of the rice variety $\mathrm{BH} 9$ in the summer season

\begin{tabular}{|c|c|c|c|c|c|}
\hline \multicolumn{2}{|c|}{ Treatment } & \multirow{2}{*}{$\begin{array}{l}\text { Plant height } \\
\quad(\mathrm{cm})\end{array}$} & \multirow{2}{*}{$\begin{array}{l}\text { Tiller number } \\
\text { (tillers per hill) }\end{array}$} & \multirow{2}{*}{$\begin{array}{l}\text { Effective tiller } \\
\text { number } \\
\text { (tillers per hill) }\end{array}$} & \multirow{2}{*}{$\begin{array}{l}\text { Leaf number } \\
\text { (leaves per tiller) }\end{array}$} \\
\hline Organic fertilizer & $\begin{array}{l}\text { HB101 spray } \\
\text { levels }\end{array}$ & & & & \\
\hline \multirow{4}{*}{0 ton ha ${ }^{-1}(\mathrm{P} 0)$} & $0 \%$ (N0) & $105.0^{\mathrm{a}}$ & $8.07^{b c}$ & $6.77^{\mathrm{ab}}$ & $10.6^{a}$ \\
\hline & $0.015 \%(\mathrm{~N} 1)$ & $111.7^{\mathrm{a}}$ & $8.00^{\mathrm{bc}}$ & $6.73^{b}$ & $11.2^{\mathrm{a}}$ \\
\hline & $0.025 \%$ (N2) & $107.9^{a}$ & $7.93^{c}$ & $6.97^{\mathrm{ab}}$ & $10.8^{a}$ \\
\hline & $0.035 \%(\mathrm{~N} 3)$ & $104.7^{\mathrm{a}}$ & $8.00^{\mathrm{bc}}$ & $7.23^{\mathrm{ab}}$ & $10.5^{\mathrm{a}}$ \\
\hline \multirow{4}{*}{4 tons ha $^{-1}(\mathrm{P} 1)$} & $0 \%$ (N0) & $110.8^{a}$ & $8.47^{a b c}$ & $7.33^{\mathrm{ab}}$ & $11.0^{\mathrm{a}}$ \\
\hline & $0.015 \%(\mathrm{~N} 1)$ & $105.5^{\mathrm{a}}$ & $8.33^{a b c}$ & $7.47^{\mathrm{ab}}$ & $10.5^{a}$ \\
\hline & $0.025 \%(\mathrm{~N} 2)$ & $105.9^{a}$ & $8.13^{\mathrm{bc}}$ & $7.13^{\mathrm{ab}}$ & $10.7^{\mathrm{a}}$ \\
\hline & $0.035 \%(\mathrm{~N} 3)$ & $107.9^{a}$ & $8.20^{\mathrm{bc}}$ & $6.73^{\mathrm{ab}}$ & $10.9^{a}$ \\
\hline \multirow{4}{*}{6 tons ha-1 $(\mathrm{P} 2)$} & $0 \%(\mathrm{NO})$ & $109.8^{a}$ & $8.20^{\mathrm{bc}}$ & $7.33^{\mathrm{ab}}$ & $10.9^{a}$ \\
\hline & $0.015 \%(\mathrm{~N} 1)$ & $111.1^{\mathrm{a}}$ & $8.60^{\mathrm{ab}}$ & $7.20^{\mathrm{ab}}$ & $11.1^{\mathrm{a}}$ \\
\hline & $0.025 \%(\mathrm{~N} 2)$ & $108.8^{\mathrm{a}}$ & $8.53^{\mathrm{abc}}$ & $7.40^{\mathrm{ab}}$ & $10.9^{a}$ \\
\hline & $0.035 \%(\mathrm{~N} 3)$ & $110.7^{\mathrm{a}}$ & $8.87^{a}$ & $7.67^{\mathrm{a}}$ & $11.1^{\mathrm{a}}$ \\
\hline $\mathrm{LSD}_{0.05 \mathrm{P} \times \mathrm{N}}$ & & 10.82 & 0.63 & 0.93 & 1.21 \\
\hline CV\% & & 5.9 & 4.3 & 8.5 & 6.6 \\
\hline
\end{tabular}

due to the fact that the application of organic fertilizer resulted in better activities of soil micro-organisms and maintenance of the necessary balance of soil nutrients, which are associated with the smooth distribution of carbohydrates in plants. Besides, the available macronutrients, especially nitrogen from the organic fertilizer combined with ionized minerals from the HB101 solution, were absorbed into the plants and cell fluid, which not only strengthened the plant cells but also led to cell division.

The effects of the organic fertilizer doses and HB101 spray levels on the bio-physiological characteristics

\section{Leaf area index}

The results showed that under all the treatments, LAI at the early growth stages increased slightly over time and at the later stages, it increased further. The maximum LAI of rice was observed at the flowering stage and then it decreased due to wilting and the falling of lower leaves (Figure 1).

The effect of the organic fertilizer doses on the LAI values at the stage of active tillering was found to be significant, and higher LAI values were observed under higher rates of organic fertilizer application (P1 and P2 treatments). However, there was no effect of the organic fertilizer doses on LAI at the other measured stages. Similar results in terms of the effects of the HB101 spray levels were observed for LAI at all three measurement times (Figure 1).

The experimental results showed significant differences in the interacting effect of the organic fertilizer doses and HB101 spray levels on LAI at all the measured stages (Table 3). At the stage of active tillering, under combinations with high rates of organic fertilizer application (P1 and $\mathrm{P} 2$ treatments), the $\mathrm{N} 3$ treatment showed a higher LAI value compared to the other HB101 application levels. Thereby, the highest LAI at this stage was obtained from the highest rates of the organic fertilizer and HB101 solution in combination. At the flowering stage, a combination of the P2 treatment with the HB101 solution recorded a higher LAI value in comparison with the other treatments; therefore, the highest LAI was shown under the P2N1 treatment. The P0N0 treatment also showed a higher LAI value as compared to the other 

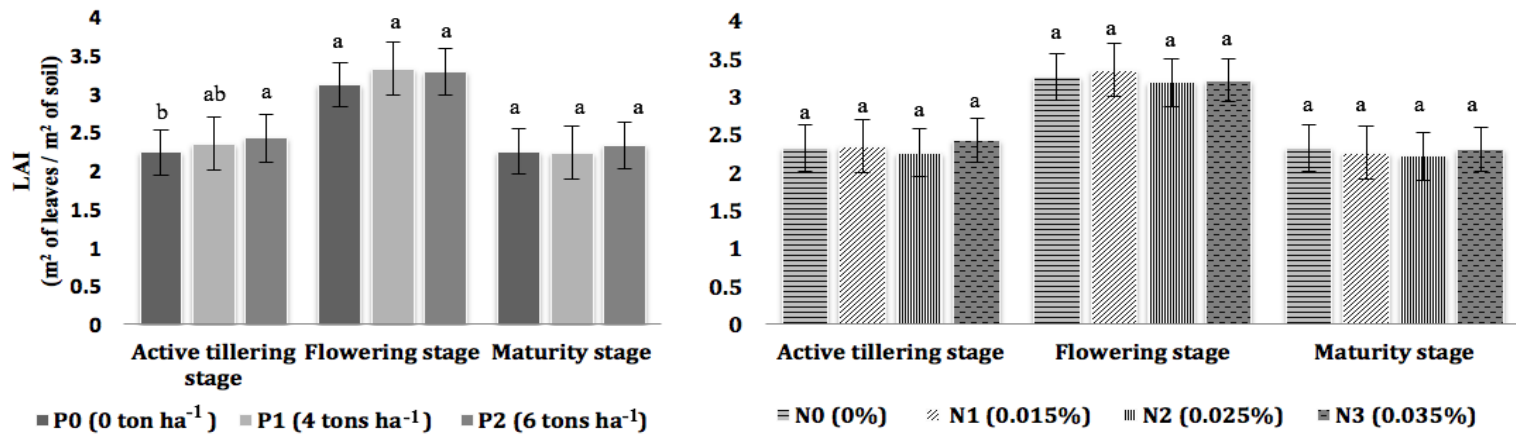

Figure 1. Effects of the organic fertilizer doses and HB101 spray levels on the LAI index of the BH9 rice variety in the summer season

Table 3. Interacting effects of the organic fertilizer doses and HB101 spray levels on the physiological indicators of the BH9 rice variety in the summer season

\begin{tabular}{|c|c|c|c|c|c|c|c|c|c|c|}
\hline \multicolumn{2}{|r|}{ Treatment } & \multicolumn{3}{|c|}{ LAI ( $m^{2}$ of leaves $/ \mathrm{m}^{2}$ of soil) } & \multicolumn{3}{|c|}{ SPAD } & \multicolumn{3}{|c|}{ Dry matter weight $\left(\mathrm{g} \mathrm{plant}^{-1}\right)$} \\
\hline $\begin{array}{l}\text { Organic } \\
\text { fertilizer }\end{array}$ & HB101 spray levels & Active tillering stage & Flowering stage & Maturity stage & $\begin{array}{c}\text { Active } \\
\text { tillering } \\
\text { stage }\end{array}$ & $\begin{array}{c}\text { Flowering } \\
\text { stage }\end{array}$ & $\begin{array}{l}\text { Maturity } \\
\text { stage }\end{array}$ & $\begin{array}{c}\text { Active } \\
\text { tillering } \\
\text { stage }\end{array}$ & $\begin{array}{l}\text { Flowering } \\
\text { stage }\end{array}$ & $\begin{array}{c}\text { Maturity } \\
\text { stage }\end{array}$ \\
\hline \multirow{4}{*}{$\begin{array}{l}0 \text { ton ha-1 } \\
\text { (P0) }\end{array}$} & $0 \%$ (N0) & $2.21^{\mathrm{bc}}$ & $3.40^{\mathrm{ab}}$ & $2.22^{\mathrm{ab}}$ & $38.69^{\mathrm{ab}}$ & $34.59^{d}$ & $31.67^{\mathrm{ab}}$ & $8.50^{f}$ & $26.35^{\mathrm{abc}}$ & $32.89^{c}$ \\
\hline & $0.015 \%(\mathrm{~N} 1)$ & $2.34^{\mathrm{abc}}$ & $3.18^{\mathrm{abc}}$ & $2.35^{\mathrm{ab}}$ & $36.14^{\mathrm{ab}}$ & $35.13^{\text {cd }}$ & $30.11^{\mathrm{b}}$ & $8.25^{\dagger}$ & $20.81^{d}$ & $38.61^{\mathrm{ab}}$ \\
\hline & $0.025 \%(\mathrm{~N} 2)$ & $2.06^{c}$ & $2.99^{b c}$ & $2.20^{\mathrm{ab}}$ & $37.97^{\mathrm{ab}}$ & $34.26^{d}$ & $32.48^{\mathrm{ab}}$ & $8.55^{\text {ef }}$ & $23.43^{\mathrm{cd}}$ & $36.58^{\mathrm{bc}}$ \\
\hline & $0.035 \%(\mathrm{~N} 3)$ & $2.34^{\mathrm{abc}}$ & $2.90^{c}$ & $2.23^{\mathrm{ab}}$ & $39.73^{a}$ & $35.47^{\mathrm{abcd}}$ & $31.25^{\mathrm{ab}}$ & $7.81^{\mathrm{g}}$ & $25.23^{a b c}$ & $36.70^{\mathrm{abc}}$ \\
\hline \multirow{4}{*}{$\begin{array}{l}4 \text { tons ha }{ }^{-1} \\
\text { (P1) }\end{array}$} & $0 \%$ (N0) & $2.27^{\mathrm{abc}}$ & $3.27^{\mathrm{abc}}$ & $2.18^{\mathrm{ab}}$ & $35.27^{b}$ & $34.29^{d}$ & $29.55^{\mathrm{b}}$ & $8.25^{\mathrm{fg}}$ & $24.11^{\mathrm{cd}}$ & $40.47^{\mathrm{ab}}$ \\
\hline & $0.015 \%(\mathrm{~N} 1)$ & $2.36^{\mathrm{abc}}$ & $3.39^{\mathrm{ab}}$ & $2.10^{\mathrm{b}}$ & $38.93^{\mathrm{ab}}$ & $36.55^{\mathrm{abc}}$ & $31.75^{\mathrm{ab}}$ & $8.43^{\mathrm{fg}}$ & $26.59^{\mathrm{abc}}$ & $40.14^{\mathrm{ab}}$ \\
\hline & $0.025 \%(\mathrm{~N} 2)$ & $2.35^{\mathrm{abc}}$ & $3.29^{a b c}$ & $2.36^{a}$ & $36.81^{\mathrm{ab}}$ & $36.99^{a b}$ & $34.83^{\mathrm{a}}$ & $9.21^{\mathrm{de}}$ & $25.93^{\mathrm{abc}}$ & $39.14^{\mathrm{ab}}$ \\
\hline & $0.035 \%(\mathrm{~N} 3)$ & $2.40^{\mathrm{ab}}$ & $3.34^{\mathrm{ab}}$ & $2.28^{\mathrm{ab}}$ & $39.80^{a}$ & $37.10^{\mathrm{a}}$ & $32.54^{\mathrm{ab}}$ & $9.67^{c d}$ & $24.32^{\mathrm{cd}}$ & $38.96^{\mathrm{ab}}$ \\
\hline \multirow{4}{*}{$\begin{array}{l}6 \text { tons ha-1 } \\
\text { (P2) }\end{array}$} & $0 \%$ (N0) & $2.49^{a b}$ & $3.08^{\mathrm{abc}}$ & $2.39^{a}$ & $40.11^{a}$ & $35.24^{\mathrm{bcd}}$ & $32.21^{\mathrm{ab}}$ & $10.73^{\mathrm{ab}}$ & $24.90^{b c}$ & $41.45^{\mathrm{ab}}$ \\
\hline & $0.015 \%(\mathrm{~N} 1)$ & $2.30^{\mathrm{abc}}$ & $3.45^{\mathrm{a}}$ & $2.30^{\mathrm{ab}}$ & $37.05^{\mathrm{ab}}$ & $35.39^{\mathrm{abcd}}$ & $32.61^{\mathrm{ab}}$ & $10.31^{\mathrm{bc}}$ & $28.89^{\mathrm{ab}}$ & $40.21^{\mathrm{ab}}$ \\
\hline & $0.025 \%(\mathrm{~N} 2)$ & $2.35^{\mathrm{abc}}$ & $3.26^{\mathrm{abc}}$ & $2.25^{\mathrm{ab}}$ & $38.07^{a b}$ & $36.05^{\mathrm{abcd}}$ & $34.51^{\mathrm{a}}$ & $11.08^{\mathrm{a}}$ & $29.08^{a}$ & $41.81^{a}$ \\
\hline & $0.035 \%(\mathrm{~N} 3)$ & $2.53^{\mathrm{a}}$ & $3.38^{\mathrm{ab}}$ & $2.38^{\mathrm{a}}$ & $38.27^{\mathrm{ab}}$ & $35.71^{\mathrm{abcd}}$ & $33.19^{a b}$ & $11.38^{\mathrm{a}}$ & $27.00^{\mathrm{abc}}$ & $40.64^{\mathrm{ab}}$ \\
\hline \multicolumn{2}{|r|}{$\mathrm{LSD}_{0.05 \mathrm{PxN}}$} & 0.33 & 0.44 & 0.26 & 4.28 & 1.83 & 4.18 & 0.69 & 4.08 & 5.21 \\
\hline \multicolumn{2}{|r|}{ CV\% } & 8.5 & 6.9 & 9.5 & 6.6 & 3.0 & 7.7 & 4.3 & 9.4 & 7.9 \\
\hline
\end{tabular}


treatments; however, the LAI values did not differ significantly with the P2N3, P1N1, and P1N3 treatments. At the maturity stage, the combinations of the highest rate of organic fertilizer application ( $\mathrm{P} 2$ treatment) with the different treatments of the HB101 solution recorded significantly higher LAI values in comparison with the others. Under the P1 and P0 treatments, higher HB101 spray levels resulted in increased LAI. However, there were no significant differences in LAI values among these treatments, excepting the P1N1 treatment, which recorded the lowest LAI at the maturity stage (Table 3).

Siddaram et al. (2010) reported that the development of leaf area is an important factor that could affect a crop's response to added nitrogen. Their study showed significant effects of various levels of nitrogen from organic sources on LAI, and they concluded that larger leaf area development aids in more interception of light leading to higher dry matter production. Similar findings were presented in the study of Srivastava (2016).

Islam et al. (2015) indicated that the increase in LAI caused by increases in the number of tillers and in the size of successive leaves was due to the presence of increased doses of N. Dash et al. (2011) showed that sufficient availability of $\mathrm{N}$ helps in vigorous growth of leaves and foliage since a higher number of leaves with expanded leaf blades are produced, hence, LAI also increases. In the present study, we recorded significant increases in LAI values due to increases in the application of the organic fertilizer and HB101 solution. More available nutrients from higher doses of organic sources by application of fertilizer and the HB101 solution increased the number of tillers and the number of leaves per hill (Table 1), leading to higher LAI values.

\section{Chlorophyll content (SPAD value)}

The data showed that the SPAD values differed dramatically under the influence of organic fertilizer rates and the HB101 spray levels only at the flowering stage. This might be due to the fact that the organic sources slowly but steadily released nitrogen $(\mathrm{N})$ during the growth stage of rice; and at the maturity stage, the $\mathrm{N}$ content decreased from manure decomposition due to plant uptake. At the flowering stage, increased doses of organic fertilizer and HB101 application tended to raise the SPAD values. At the other stages, the P2 treatment recorded higher SPAD readings as compared to the $\mathrm{P} 1$ and $\mathrm{P} 0$ treatments, however, no significant differences were found among the treatments of the organic fertilizer rates. Besides, higher HB101 applications led to increased SPAD values only at the flowering stage (Figure 2).

The results in Table 3 show that the interacting effects of the organic fertilizer doses and HB101 spray levels on the SPAD values of the $\mathrm{BH} 9$ rice variety were significantly different at all three measurement times. At the active tillering stage, the P2N0, P1N3, and P0N3 treatments recorded dramatically higher SPAD values than the other treatments, however, there was no difference among them. The data supports that higher applications of organic fertilizer and the HB101 solution might cause increased SPAD values on rice at this stage.

At the flowering stage, under the P1 treatment, high levels of HB101 dramatically increased the SPAD values in comparison with the $\mathrm{P} 2$ treatment, excepting the P1N0 treatment, which showed the lowest SPAD reading. Under the P2 treatment, higher HB101 applications reported higher SPAD values; however, this parameter was on par with the P2N1, P2N2, and $\mathrm{P} 2 \mathrm{~N} 3$ treatments. In terms of a combination of the P0 treatment and HB101 solution, the SPAD value was lower than the other treatments. At the maturity stage, under the P1 and P2 treatments, higher levels of HB101 application reported higher SPAD readings. Besides, the N2 treatment showed the highest SPAD values under combinations with different rates of organic fertilizer application.

Similar results with the present study were reported in different previous studies. Myint et al. $(2010,2011)$ indicated that greater SPAD values were observed in response to a higher application of different types of organic 

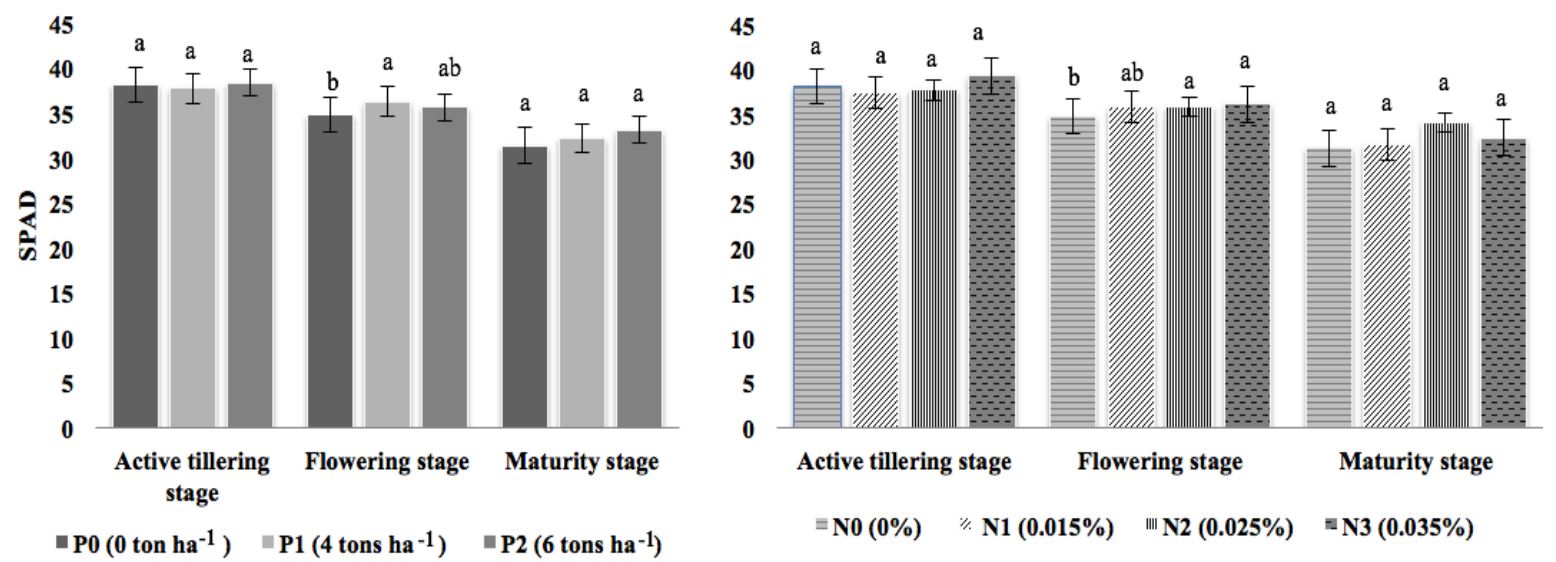

Figure 2. Effects of the organic fertilizer doses and HB101 spray levels on the SPAD values of the BH 9 rice variety in the sumer season

manures due to higher decomposable nutrient contents. The lower SPAD values in the different treatments might have been due to shortages of available nutrients (especially $\mathrm{N}$ ) in the soil since the nutrients in the decomposable organic matter had been decreased by plant uptake. The organic manure treatments produced fluctuations in the SPAD values at all the growth stages, and these were higher than those of the treatments without fertilizer applications (Moe et al., 2017).

The study of Erdal et al. (2016) showed that there are close correlations between the SPAD reading, leaf greenness, chlorophyll content, and nutrient contents, including nitrogen, magnesium, and iron, and these elements play a vital role in chlorophyll synthesis. In our study, we recorded significant differences in SPAD values among all the treatments, which tended to increase under high doses of the organic fertilizer and HB101 solution at all the measured stages. This was due to the fact that the higher availability of different nutrients from the organic sources of fertilizer and HB101 led to more nutrients being absorbed into the plants and transferred to the upper leaves, which resulted in greener leaves, higher SPAD values, and a higher photosynthetic efficiency.

\section{Dry matter weight}

The experimental results showed that the dry matter of the $\mathrm{BH} 9$ rice variety samples significantly differed at all the growing stages under the influence of the organic fertilizer and increases in the organic fertilizer rate led to increased dry matter weight. The highest dry matter weight was recorded under the P2 treatment, which was significantly different from the P1 and P0 treatments at the flowering stage and was on par with the P1 treatment at the maturity stage. In terms of the HB101 solution, high levels of this factor resulted in higher dry matter accumulation; however, there were no significant differences among the treatments at the flowering and maturity stages. At the active tillering stage, the N2 and N3 treatments dramatically increased the rice dry matter as compared to the N0 and N1 treatments, which were on par with each other (Figure 3).

It can be observed that the combination of the organic fertilizer and HB101 solution dramatically affected the dry matter accumulation of the $\mathrm{BH} 9$ rice variety at all the growing stages (Table 3). Higher applications of the organic fertilizer and HB101 solution tended to increase the dry matter weight at the three measurement times. It seems that the nutrients released from this combination could have helped in balancing the availability of nutrients and enhanced the soil's physical, chemical, and biological properties at all the stages. Rao et al. (2014) showed that the improved uptake of nutrients led to increased chlorophyll formation and improved photosynthesis, thereby increasing the plant 

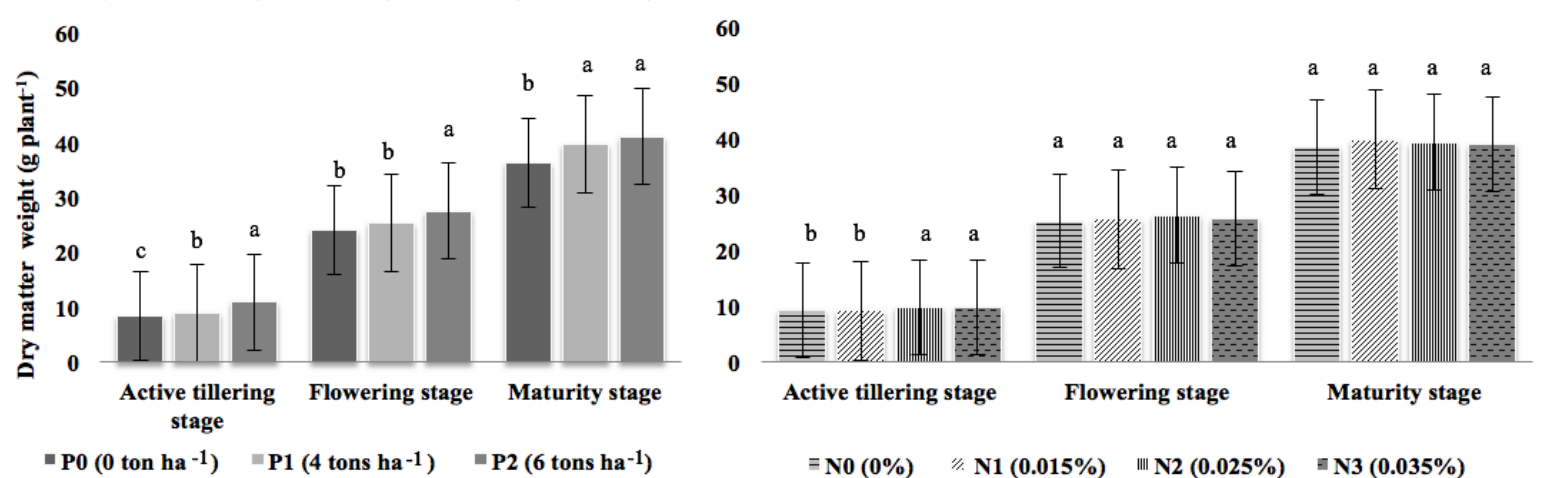

Figure 3. Effects of the organic fertilizer doses and HB101 spray levels on the dry matter weight of the BH9 rice variety in the summer season

height, the number of leaves, and the number of tillers per unit area. This led to the production of higher dry matter in rice. Gautam (2013) reported that the application of organic manure had a significant effect on dry matter accumulation. The dry matter accumulation was highest with the highest application of organic manure $\left(20\right.$ tons $\left.\mathrm{ha}^{-1}\right)$ and was reduced when the applied organic manure rate was decreased. This may be due to the fact that organic manure provides better growing conditions for plants through a continuous supply of nutrients and improvement of soil properties.

The role of nutrient sources has long been recognized to have positive effects on rice, causing significant increases in dry matter production and LAI with every increase in the level of fertility (Srivastava et al., 2016). Myint et al. (2010) reported that among all applications, high levels of poultry manure in the experimental soil gave the highest dry matter rates, which might be due to the greater nutrient availability and high major nutrients content (such as $\mathrm{N}, \mathrm{P}$, and $\mathrm{K}$ ) of the poultry manure. Siavoshi et al. (2011) recorded more dry matter accumulation in response to increases in the applied dose of organic manure and more dry matter accumulation was observed under the treatment of 2.0 tons $\mathrm{ha}^{-1}$ organic fertilizer. The results were similar in the study of Srivastava et al. (2016). In the present study, higher dry matter production was perhaps due to the higher leaf dry weights and stem dry weight recorded at the different stages. More photosynthetically active leaf areas resulted in higher dry matter accumulation. This was also reported in the study of Gautam (2013). In addition, nitrogen might have been involved in the various physiological activities like increased photosynthetic activity and better light interception, which, in turn, resulted in higher dry matter accumulation (Siddaram et al., 2010).

The effects of the fertilizer doses and spray levels of the HB101 solution on the yield parameters and grain yield

The results presented in Table 4 indicate that there were differences in the number of panicles per $\mathrm{m}^{2}$, potential yield, and grain yield with increased levels of organic fertilizer application, however, the organic fertilizer did not affect the number of grains per panicle or the 1000 grain weight. All the parameters were progressively augmented by incremental levels of fertilizer up to the highest dose tested. The P2 treatment significantly increased the mean grain yield (2.82 tons ha ${ }^{-1}$ ) as compared to the P1 and P0 treatments, which were on par with each other. In terms of the HB101 solution, this factor did not influence the yield components or grain yield of the rice variety $\mathrm{BH} 9$ in the summer season, excepting the 1000 grain weight parameter. However, higher applications of the HB101 solution (N2 and N3 treatments) led to increases in all the parameter values as compared to the $\mathrm{N} 0$ and $\mathrm{N} 1$ treatments.

The interactive effects of the organic fertilizer doses and HB101 spray levels on the yield attributes and grain yield are shown in Table 5. It was reported that the combination of 
Effects of organic fertilizer and HB101 plant vitalizer on the growth and yield of rice

Table 4. Effects of the organic fertilizer doses and HB101 spray levels on the yield components of the BH9 rice variety in the summer season

\begin{tabular}{|c|c|c|c|c|c|}
\hline Treatment & $\begin{array}{c}\text { Number of } \\
\text { panicles per } \mathrm{m}^{2}\end{array}$ & $\begin{array}{l}\text { Number of grains } \\
\text { per panicle }\end{array}$ & $\begin{array}{c}1000 \text { grain weight } \\
\text { (g) }\end{array}$ & $\begin{array}{l}\text { Filled grains rates } \\
\qquad(\%)\end{array}$ & $\begin{array}{l}\text { Grain yield } \\
\text { (tons ha-1) }\end{array}$ \\
\hline \multicolumn{6}{|c|}{ Organic fertilizer doses } \\
\hline 0 ton ha ${ }^{-1}(\mathrm{P} 0)$ & $172.92^{\mathrm{b}}$ & $143.03^{a}$ & $23.69^{a}$ & 74.08 & $2.27^{b}$ \\
\hline 4 tons ha ${ }^{-1}(\mathrm{P} 1)$ & $177.78^{\mathrm{ab}}$ & $150.13^{a}$ & $23.59^{a}$ & 73.45 & $2.50^{\mathrm{b}}$ \\
\hline 6 tons ha $^{-1}(\mathrm{P} 2)$ & $186.81^{a}$ & $151.46^{a}$ & $24.02^{\mathrm{a}}$ & 74.57 & $2.81^{a}$ \\
\hline $\mathrm{LSD}_{0.05 \mathrm{P}}$ & 10.51 & 11.49 & 0.54 & - & 0.27 \\
\hline \multicolumn{6}{|c|}{ HB101 spray levels } \\
\hline $0 \%(\mathrm{~N} 0)$ & $175.93^{a}$ & $143.60^{\mathrm{a}}$ & $23.66^{a b}$ & 74.81 & $2.52^{\mathrm{a}}$ \\
\hline $0.015 \%(\mathrm{~N} 1)$ & $176.85^{a}$ & $147.23^{a}$ & $23.27^{b}$ & 74.47 & $2.37^{a}$ \\
\hline $0.025 \%(\mathrm{~N} 2)$ & $186.11^{\mathrm{a}}$ & $155.38^{a}$ & $23.90^{\mathrm{a}}$ & 72.11 & $2.66^{a}$ \\
\hline $0.035 \%(\mathrm{~N} 3)$ & $177.78^{a}$ & $146.61^{a}$ & $24.24^{\mathrm{a}}$ & 74.75 & $2.56^{a}$ \\
\hline $\operatorname{LSD}_{0.05 \mathrm{~N}}$ & 12.13 & 13.26 & 0.63 & - & 0.31 \\
\hline
\end{tabular}

Table 5. Interacting effects of the organic fertilizer doses and HB101 spray levels on the yield components of the BH9 rice variety in the summer season

\begin{tabular}{|c|c|c|c|c|c|c|}
\hline \multicolumn{2}{|c|}{ Treatment } & \multirow{2}{*}{$\begin{array}{c}\text { Number of } \\
\text { panicles per } \\
\mathrm{m}^{2}\end{array}$} & \multirow{2}{*}{$\begin{array}{l}\text { Number of grains } \\
\text { per panicle }\end{array}$} & \multirow{2}{*}{$\begin{array}{l}1000 \text { grain } \\
\text { weight } \\
(\mathrm{g})\end{array}$} & \multirow{2}{*}{$\begin{array}{l}\text { Filled grains } \\
\text { rates } \\
(\%)\end{array}$} & \multirow{2}{*}{$\begin{array}{l}\text { Grain yield } \\
\text { (tons ha }^{-1} \text { ) }\end{array}$} \\
\hline $\begin{array}{l}\text { Organic } \\
\text { fertilizer }\end{array}$ & $\begin{array}{l}\text { HB101 spray } \\
\text { levels }\end{array}$ & & & & & \\
\hline \multirow{4}{*}{$\begin{array}{l}0 \text { ton ha-1 } \\
\text { (P0) }\end{array}$} & $0 \%$ (N0) & $161.11^{c}$ & $139.21^{\text {bc }}$ & $23.87^{\mathrm{abc}}$ & 76.86 & $2.05^{\mathrm{cd}}$ \\
\hline & $0.015 \%(\mathrm{~N} 1)$ & $177.78^{\mathrm{abc}}$ & $149.57^{\mathrm{abc}}$ & $23.12^{\mathrm{c}}$ & 72.57 & $2.00^{d}$ \\
\hline & $0.025 \%(\mathrm{~N} 2)$ & $180.56^{\mathrm{abc}}$ & $151.18^{\mathrm{abc}}$ & $23.72^{\mathrm{abc}}$ & 72.28 & $2.44^{\mathrm{bcd}}$ \\
\hline & $0.035 \%(\mathrm{~N} 3)$ & $172.22^{\mathrm{bc}}$ & $132.16^{c}$ & $24.07^{\mathrm{ab}}$ & 74.62 & $2.57^{a b c}$ \\
\hline \multirow{4}{*}{$\begin{array}{l}4 \text { tons } \text { ha }^{-1} \\
\text { (P1) }\end{array}$} & $0 \%$ (N0) & $180.56^{\mathrm{abc}}$ & $146.27^{\mathrm{abc}}$ & $23.28^{\mathrm{abc}}$ & 75.61 & $2.61^{\mathrm{ab}}$ \\
\hline & $0.015 \%(\mathrm{~N} 1)$ & $175.00^{\mathrm{abc}}$ & $139.79^{b c}$ & $22.83^{c}$ & 72.44 & $2.39^{\mathrm{bcd}}$ \\
\hline & $0.025 \%(\mathrm{~N} 2)$ & $177.78^{\mathrm{abc}}$ & $164.44^{\mathrm{a}}$ & $23.90^{\mathrm{abc}}$ & 72.15 & $2.50^{\mathrm{abcd}}$ \\
\hline & $0.035 \%(\mathrm{~N} 3)$ & $177.78^{\mathrm{abc}}$ & $150.00^{\mathrm{abc}}$ & $24.34^{\mathrm{a}}$ & 73.60 & $2.51^{\mathrm{abcd}}$ \\
\hline \multirow{4}{*}{$\begin{array}{l}6 \text { tons ha-1 } \\
\text { (P2) }\end{array}$} & $0 \%$ (NO) & $186.11^{\mathrm{ab}}$ & $145.32^{\mathrm{abc}}$ & $23.82^{\mathrm{abc}}$ & 71.98 & $2.90^{\mathrm{ab}}$ \\
\hline & $0.015 \%(\mathrm{~N} 1)$ & $177.78^{\mathrm{abc}}$ & $152.32^{\mathrm{abc}}$ & $23.87^{\mathrm{abc}}$ & 78.39 & $2.74^{\mathrm{ab}}$ \\
\hline & $0.025 \%(\mathrm{~N} 2)$ & $200.00^{\mathrm{a}}$ & $150.51^{\mathrm{abc}}$ & $24.08^{\mathrm{ab}}$ & 71.89 & $3.03^{\mathrm{a}}$ \\
\hline & $0.035 \%(\mathrm{~N} 3)$ & $183.33^{\mathrm{ab}}$ & $157.67^{\mathrm{ab}}$ & $24.32^{\mathrm{a}}$ & 76.02 & $2.59^{\mathrm{ab}}$ \\
\hline $\mathrm{LSD}_{0.05 \mathrm{P} \times \mathrm{N}}$ & & 21.02 & 22.98 & 1.09 & - & 0.54 \\
\hline CV\% & & 6.9 & 9.2 & 2.7 & - & 12.6 \\
\hline
\end{tabular}

the two factors significantly affected all the yield components and grain yield of rice, and the applications with the high fertilizer (treatments P2 and P1) and high levels of HB101 resulted in increased values of these parameters.

The maximum number of panicles per $\mathrm{m}^{2}$ was recorded in the plants treated with $\mathrm{P} 2 \mathrm{~N} 2$ and was followed by $\mathrm{P} 2 \mathrm{~N} 0$ and $\mathrm{P} 2 \mathrm{~N} 3$, which were on par with each other, whereas the lowest value was reported under the P0N0 treatment. All the remaining treatments were similar for this parameter.

The maximum number of grains per panicle was observed in the plots with the P1N2 treatment (164.44 grains) and was followed by the $\mathrm{P} 2 \mathrm{~N} 3$ treatment (157.67 grains), whereas the 
minimum number of grains per panicle was noted in the P0N3 treatment (132.16 grains).

In terms of the 1000 grain weight, the P2N3 and $\mathrm{P} 1 \mathrm{~N} 3$ treatments significantly increased this parameter as compared to the other treatments (24.34g and $24.31 \mathrm{~g}$, respectively), however, the values were not significantly different from each other. The lower applications of fertilizer (P0 and P1) with the N1 treatment reported the lowest values of grain weight with $23.12 \mathrm{~g}$ and $22.83 \mathrm{~g}$, respectively.

Grain yield of the $\mathrm{BH} 9$ rice variety fluctuated from 2.00 tons $\mathrm{ha}^{-1}$ to 3.03 tons $\mathrm{ha}^{-1}$. Under higher doses of fertilizer, the treatments with the HB101 solution gave increased values of grain yield as compared to lower organic fertilizer dose. Application of the P2N2 treatment gave the highest significant increment of the rice yield compared with the other treatments. It was followed by the P2N0, P1N0, and P2N3 treatments with yields of 2.90 tons $\mathrm{ha}^{-1}, 2.61$ tons $\mathrm{ha}^{-1}$ and 2.59 tons $\mathrm{ha}^{-1}$, respectively, and they were on par with each other. The minimum grain yield was recorded in the $\mathrm{PON} 1$ and $\mathrm{P} 0 \mathrm{~N} 0$ treatments with approximately 2 tons $\mathrm{ha}^{-1}$ each. It seems that the nutrients released from the organic fertilizer play a more important role than the HB101 solution. This is in line with the above observations as the organic fertilizer doses directly affected the formation of grain yield.

In previous studies, Bagayoko et al. (2012) and Moe et al. (2017) did not record significant differences in yield and yield components under the applications of different doses and kinds of organic manures. Moe et al. (2017) showed that the application of organic manure alone did not significantly enhance the yield and yield attributes of rice in a cropping season, which can be explained by severe deficiencies in nitrogen at the vegetative stage. Bagayoko et al. (2012) indicated that the manure effects were very heterogeneous and high rates did not necessarily increase crop yields. Ghoneim et al. (2007) recorded increases in grain yield to $34.8 \%$ under the application of poultry manure over the control without fertilizer. This was consistent with the findings of Myint et al. (2011) and Dash et al. (2011), who considered that this might be due to the quick release of a number of nutrients like $\mathrm{N}$ and $\mathrm{P}$ from the organic inputs.

In the present study, we observed that the effects of the organic fertilizer application on grain yield and the number of panicles per $\mathrm{m}^{2}$ were significant; and high doses of fertilizer led to increases in grain yield and yield components, which can be explained by the increase in nutrient contents, especially $\mathrm{N}$, from the organic fertilizer. These results are similar to the study of Gautam et al. (2013), who showed that with the increasing levels of fertilizer, grain yield increased significantly and consistently, and achieved the highest increases with the highest fertilizer level (20 tons ha $\left.{ }^{-1}\right)$. According to the authors, the increase of rice grain yield under the organic manure treatment may have been due to the fact that the slow releasing nutrients from the organic manure over a long period increased the availability of nitrogen and the efficiency of the applied or native soil phosphorus due to the solubilizing effect of organic acids produced during decomposition of organic manures (Srivastava et al., 2016).

Siavoshi et al. (2011) explained that the increase in grain yield components was due to the better water holding capacity of the soil as a result of more organic material applications leading to more available water in the soil, which enhanced nutrient availability and improved nutrient absorption as well as increased the production and translocation of the dry matter content. There were no differences among the yield components, potential yield, and grain yield under the effects of the HB101 solution, which may be due to the fact that the HB101 solution works to maintain the proper balance of soil micro-organisms, and its ionized minerals combined with the plant nutrients from the organic fertilizer caused the strengthening of the leaf, stem, and root systems, thereby improving the growth processes and immune function of the plants. These results were similar to the study of Mohammadi et al. (2013) in terms of the effects of the HB101 solution on potato. The authors observed that there was no effect of the HB101 solution on potato yields; however, the 
combination of HB101 with other fertilizers showed positive effects on the potato traits.

\section{Conclusions}

The results indicated significant increases in the growth and yield of the $\mathrm{BH} 9$ rice variety in the summer season under applications of different doses of organic fertilizer and the HB101 plant vitalizer. Organic fertilizer alone and the integration of organic fertilizer and the HB101 solution showed significant effects on the number of total tillers, the number of effective tillers, dry matter weight, LAI values, SPAD values, grain yield, and yield components. In general, high rates of organic fertilizer application and high HB101 spray levels resulted in increases in the growth and yield of rice by increasing the number of tillers, effective tillers, physiological parameters (LAI, SPAD, and dry matter accumulation), grain yield, and all the yield attribute parameters. The P2N2 treatment (6 tons ha ${ }^{-1}$ of organic fertilizer combined with the HB101 spray level of $0.025 \%$ ) gave the highest grain yield with 3.03 tons $\mathrm{ha}^{-1}$, which was significantly higher than the rest of the treatments. Besides, the application of the HB101 solution with the organic fertilizer dose of 6 tons ha ${ }^{-1}$ also showed higher grain yield of the $\mathrm{BH} 9$ rice variety in the summer season.

\section{Acknowledgements}

We acknowledge the People's Committee and the Farmer Association of Hong Thai commune, Kien Xuong district, Thai Binh province, Vietnam for facilitating and supporting the experimental arrangement in the field experiments.

\section{References}

Bagayoko M. (2012). Effect of plant density, organic matter and nitrogen rates on rice yields in the system of rice intensification (SRI) in the "office du Niger" in Mali. ARPN Journal of Agricultural and Biological Science. 7(8): 620-632.

Dash D. A., Patro H., Tiwari R. C. \& Shahid M. (2011). Effect of organic and inorganic sources of $\mathrm{N}$ on growth attributes, grain and straw yield of rice (Oryza sativa). International Journal of Pharmaceutical and Life Sciences. 2(4): 655-660.

Erdal I., Turkmen R. \& Akgun A. (2016). Variation in chlorophyll, SPAD value and some nutrient concentrations depending on Chlorosis in Peach leaves. Lucrari Stiintifice. 59(2): 13-16.

Gafar A. F., Yassin M. I. D. \& Samia O. Y. (2014). Effect of different fertilizers (bio, organic and inorganic fertilizers) on some yield components of rice (Oryza Sativa L.). Universal Journal of Agricultural Research. 2(2): 67-70.

Gautam P., Sharma G. D., Rana R. \& Lal B. (2013). Effect of integrated nutrient management and spacing on growth parameters, nutrient content and productivity of rice under system of rice intensification. International Journal of Research in BioSciences. 2(3): 53-59.

Ghoneim A. (2007). Effect of nitrogen supplied from poultry manure and sewage sludge on growth, yield and nitrogen uptake of rice. Bulletin of Experimental Farm, Faculty of Agriculture, Ehime University. 29: 11-16.

Islam M. S., Paul N. K., Alam M. R., Uddin M. R., Sarker U. K., Islam M. A. \& Park S. U. (2015). Responded of rice to green manure and nitrogen fertilizer application. Online Journal of Biological Science. 15(4): 207-216.

Javier E. F., Marquez J. M., Grospe F. S., Mamucod H. F. \& Tabien R. E. (2002). Three-year effect of organic fertilizer use on paddy rice. Philippine Journal of Crop Science. 27(2): 11-15.

Liu C. W., Sung Y., Chen B. C. \& Lai H. Y. (2014). Effects of nitrogen fertilizers on the growth and nitrate content of lettuce (Lactuca Sativa L.). International Journal of Environmental Research and Public Health. 11(4): 4427- 4440.

Moe K., Win M. K., Win K. K. \& Yamakawa T. (2017). Combined effect of organic manures and inorganic fertilizers on the growth and yield of hybrid rice (Palethwe - 1). American Journal of Plant Sciences. 8: 1022-1042.

Mohammadi G. R., Ajirloo R. A., Ghobadi M. E. \& Najaphy A. (2013). Effects of non-chemical and chemical fertilizers on potato (Solanum tuberosum L.) yield and quality. Journal of Medicinal Plants Research. 7(1): 36-42.

Myint A. K., Yamakawa T., Kajihara Y. \& Zenmyo T. (2010). Application of different organic and mineral fertilizers on the growth, yield and nutrient accumulation of rice in Japanese ordinary paddy yield. Science World Journal. 5(2): 47-54. 
Myint A. K., Yamakawa T., Zenmyo T., Hoang T. B. T \& Sarr P. S. (2011). Effects of organic-manure application on growth, grain yield, and nitrogen, phosphorus, and potassium recoveries of rice variety Manawthuka in paddy soils of differing fertility. Communications in Soil Science and Plant Analysis. 42: 457-474.

Ohyama N., Katono M. \& Hasegawa T. (1998). Effects of long term application of organic materials to the paddy field originated from Aso volcanic ash on the soil fertility and rice growth. I. Effects on the rice growth and nutrient uptake for the initial three years. Proceeding of Faculty of Agriculture, Kyushu Tokai University. 17: 9-24.

Rao T. K., Rao U. A., Sekhar D., Ramu P. S. \& Rao V. N. (2014). Effect of different doses of nitrogen on performance of promising varieties of rice in high altitude areas of Andhra Pradesh. International Journal of Farm Sciences. 4(1): 6-15.

Siavoshi M., Nasiri A. \& Lawre S. (2011). Effect of organic fertilizer on growth and yield in rice (Oryza sativa L.). Journal of Agricultural Science. 3(3): 217224.

Siddaram M. D., Murali K., Manjunatha B. N., Ramesha Y. M., Basavaraja M. K. \& Policepatil A. S. (2010). Effect of nitrogen levels through organic sources on growth, dry matter production and nutrient uptake of irrigated aerobic rice (Oryza sativa L.). International Journal of Agricultural Sciences. 6(2): 426-429.

Singh S., Bohra J. S., Singh Y. V., Upadhyay A. K., Verma S. S., Mishra P. K. \& Raghuveer M. (2017). Effect of integrated nutrient management on growth and development stages of rice under rice-wheat ecosystem. International Journal of Current Microbiology and Applied Sciences. 6(7): 2032-2042.

Srivastava V. K., Singh J. K. \& Vishwakarma A. (2016). Effect of fertility levels and mode of nitrogen nutrition $\mathrm{n}$ productivity and profitability of hybrid rice under system of rice intensification. International Journal of Agriculture Sciences. 8(47): 1983-1986. 